\title{
Linking transformational leadership and organizational trust: has organizational commitment a mediating effect on it?
}

\author{
Relacionando liderazgo transformacional y \\ confianza organizacional: $₫$ Tiene el compromiso \\ organizacional un efecto mediador?
}

\author{
Orlando Manuel Martins Marques De Lima Rua ${ }^{1}$ \\ João Manuel Costa Araújo ${ }^{2}$ \\ Polytechnic of Porto (Portugal) \\ University of Porto (Portugal)
}

Recibido el 30 de mayo de 2014, aceptado el 6 de marzo de 2015

$\mathrm{N}^{\circ}$ de clasificación JEL: M1

DOI: $10.5295 / \mathrm{cdg} .140484$ om

\begin{abstract}
:
The main goal of this study is to analyze how organizational commitment has a mediating effect on the relation between transformational leadership and organizational trust.

Therefore we developed an organization analysis based on a survey that was used to collect primary data from a sample of 58 employees. We obtained a $71 \%$ response rate and these data were analyzed using quantitative methodological techniques and linear regression. The research was conducted at the Serralves Foundation (Porto, Portugal) to empirically test the proposed research model and its hypotheses.

The empirical results confirm that transformational leadership positively enhances organizational trust. However, transformational leadership and organizational trust are not significantly influenced by organizational commitment, thus not having a mediating effect on this relationship. Such results assume particular relevance because they become a basis for comparative studies in similar organizations.

This study brings some theoretical contributions to the literature by analyzing the mediating effect of organizational commitment on the relation between transformational leadership and organizational trust in cultural organizations and has also some practical management implications, as it draws attention to the importance of a set of practices, job satisfaction oriented, which can effectively lead to organizational commitment intervention in the relationship between transformational leadership and organizational trust.
\end{abstract}

\footnotetext{
${ }^{1}$ Applied Management Research Unit (UNIAG), Portuguese Northern Polytechnic Association; Center for Studies in Business and Legal Sciences (CECEJ), School of Accounting and Administration of Porto (ISCAP), Polytechnic of Porto (IPP), Rua Jaime Lopes Amorim, s/n, 4465-004 S. Mamede de Infesta (Portugal). orua@iscap.ipp.pt

${ }^{2}$ Faculty of Letters (FL), University of Porto (UP), Via Panorâmica, s/n, 4150-564 Porto (Portugal). joao.c.araujo@ gmail.com
} 
Linking transformational leadership and organizational trust: has organizational commitment a mediating effect on it?

\section{Keywords:}

Transformational leadership, organizational trust, organizational commitment.

\section{Resumen:}

El objetivo principal de este trabajo es analizar si el compromiso organizacional ejerce un efecto mediador entre la relación del liderazgo transformacional y la confianza organizacional.

Con esta finalidad desarrollamos el análisis de una organización basado en una encuesta que se utilizo para recoger datos primarios de una muestra de 58 empleados. Se obtuvo una tasa de respuesta del $71 \%$ y estos datos fueron analizados usando técnicas metodológicas cuantitativas y regresión lineal. La investigación se realizó en la Fundación Serralves (Porto, Portugal) para probar empíricamente el modelo de investigación propuesto y testar sus hipótesis.

Los resultados empíricos confirman que el liderazgo transformacional refuerza positivamente la confianza organizacional. Por el contrario, destaca que el liderazgo transformacional y la confianza organizacional no están influenciados de modo significativo por el compromiso organizacional y que este último no tiene un efecto mediador en la relación descrita anteriormente.

Este estudio proporciona algunas aportaciones a la literatura a través del análisis del efecto mediador del compromiso organizativo sobre la relación entre el liderazgo transformacional y la confianza en la cultura organizativa, así como implicaciones para la gestión, destacando la importancia de un conjunto de prácticas, orientadas a la satisfacción en el trabajo, que efectivamente pueden conducir a la intervención de compromiso organizacional en la relación entre liderazgo transformacional y confianza organizacional.

\section{Palabras clave:}

Liderazgo transformacional, confianza organizacional, compromiso organizacional. 


\section{INTRODUCTION}

This research analyzes the relationship between transformational leadership and organizational trust and the possibility of organizational commitment having a mediating effect in this relationship.

An organization's lack of competitiveness can be associated with low productivity and, in most cases, is attributed to leadership styles that do not promote organizational trust and commitment of human resources in achieving the organizational goals.

With an increasingly competitive and demanding external environment, characterised by systematic changes and the search for better performances, it is essential for an organization to attain new skills and improve communication, motivate the teams, adopt assertive attitudes and acquiring the ability to manage even better organizational knowledge in order to achieve leverage results. This will require a leadership with vision and concrete action that consolidate processes which in turn ensure the implementation of comprehensive and flexible strategies. A determined leadership is a complex reality that can lead the individual to overcome and transcend limits, thus promoting personal development, creating a permanent dynamic incentive, and retaining the best of each individual. Organizations need committed employees who can maintain high levels of confidence (Rua and Araújo 2013).

Some studies suggest that confidence increases the levels of satisfaction and commitment to the organization, reducing stress in interpersonal relationships (Costa 2002), the confidence in supervisors and leaders also generates a positive effect on group performance (Dirks and Ferrin 2001), in the voluntary acceptance of the hierarchy decisions, as well as a mediating role in the manifestation of organizational citizenship behaviors, both in relation to superiors and peers (Podsakoff et al. 1990).

This new leadership is reflected in the leader's ability to listen and respect the ideas of employees; anticipate change; stimulate creativity and knowledge; delegate; communicate in dialogue form, by applying holistic and democratic principles. In this sense, transformational leadership has assumed a growing importance due to the results generally obtained both at individual and organizational levels (Rua and Araújo 2013).

Some researchers suggest theoretical models to comprehend the processes through which transformational leadership is positively related to the follower's attitudes, behavior and performance (e.g. Bass 1985; Yukl 1989; Kark and Shamir 2002). According to Zhu and Akhtar (2014), trust has a central role in these models because it reduces the uncertainty and risk associated with change.

To our knowledge, however, no study has tested explicitly the mediating effect of organizational commitment on the relationship between transformational leadership and organizational trust. For that reason, testing this effect is the main motivator for developing the present study, which has practical implications to the studied organization. 


\section{LITERATURE REVIEW}

\subsection{Transformational leadership}

Transformational leadership was originally developed by Burns (1978), and has captured scholars' interest over the last decades (e.g. Bass 1985; Avolio and Bass 1991; Conger 1999; Kanungo 2001; Judge and Piccolo 2004). Through strong vision and personality, transformational leaders are able to inspire followers to change expectations, perceptions and motivations to work towards common goals (Cherry 2010).

Transformational leadership refers to the process by which leaders foster the commitment of followers and induce them to overcome their self-interests in favour of the objectives of the organization, obtaining their commitment and producing major changes and high performance (Rego and Cunha 2007).

The transformational leader must be able to identify and express to employees a clear vision of the future, providing appropriate examples and defending the organization's goals. Furthermore, the leader must have the ability to persuade employees to place common objectives before individual goals. This type of leader shows respect for employees and is concerned with the individuality of each one (Schwepker and Good 2010). A transformational leader must recognise and meet the needs of subordinates and also stimulate an environment that enables each one to develop and prosper, in order to maximise and expand his or her potential.

Transformational leadership manifests a strong potential to inspire followers to higher levels of enthusiasm, dedication, commitment and extra effort that drive the organization to excellent performance. It is based on employees' empowerment in relations of trust, loyalty, justice, and in the increase of employees' self-efficacy, self-confidence and self-worth (Rego and Cunha 2007). To meet the challenges of a constantly changing environment, the development of transformational leadership behaviours should be seen as highly beneficial, surpassing the results of classical organizational development programmes (Abrell et al. 2011).

In order to address the development needs of today's leaders, who face a challenging and constantly changing environment, the development of transformational leadership behaviours should be seen as highly beneficial, surpassing the results of classical organizational development programmes (Abrell et al. 2011).

\subsection{Organizational trust}

Despite the multiplicity of concepts, there is a consensus on the existence of a degree of interdependence between the one who offers trust and the one who trusts. Fukuyama (1995) characterizes trust as the product of shared ethical norms related with reciprocity, moral obligation, and duty toward community, including honesty, reliability, cooperativeness, and a sense of responsibility to others. Mehrabi et al. (2012) believe that trust is the confidence that one person has in another in a way that he/her acts through a predictable, behavioral and fair conduct.

In this perspective, trust is defined as a psychological state, which depends on expectations related to the behaviour of others. Thus, trust is analyzed as the result of predispo- 
sition to trust (both at the individual or group level), the characteristics of individuals in whom you trust and situational conditions (Freire 2008).

The idea of organizational trust has raised an interesting set of reflections and hypotheses on the role of confidence processes in the functioning of organizations. An essential idea common to various approaches to organizational trust, is based on the fact that an organization should ensure cooperation between people with different interests, although the organization's systems of power and authority assume in most cases the exercise of a unitary and consistent power. The effectiveness of this exercise of power to ensure cooperation is becoming better understood as resulting not from pure and simple coercion, but from autonomous acceptance, and thus, conditional exercise of power by those whose cooperation is needed (Keating et al. 2010).

Therefore, trust is an essential part of efficiency and performance of an organization (van der Berg and Martins 2013), and is the employee's expectation on the reliability in the organization's promises and actions (Politis 2003). Trust increases the efficiency and effectiveness of communication (Blomqvist 2002), as well as organizational cooperation and collaboration (Mayer et al. 1995; Tyler 2003). It has also been identified as a critical factor in leadership effectiveness (Tyler 2003), employee satisfaction (Shockley-Zalabak et al.2000), commitment (Dirks and Ferrin 2001), productivity (Huang et al. 2007; Kerce and Booth-Kewley 1993; May et al. 1999) and performance (Barney and Hansen 1994).

Also noteworthy is that trust can be a difficult and time-consuming process to create, it can result from repeated actions over prolonged periods of time in order to achieve a slow evolution, once established; it may easily be lost or wasted by erroneous attitudes or behaviours (Connell and Mannion 2006).

Bibb and Kourdi (2004) state that when trust exists within an organization different results can be achieved. To achieve individual and organizational objectives, interdependence between different people and different life experiences is necessary. This interdependence is facilitated by trust.

We cannot have absolute control over the actions of others, nor understand the motivations and interpersonal relationships of each one. People need to relate and develop specific mechanisms of protection, without which they could not keep more than casual relationships. For Rua and Araújo (2013) trust is an efficient mechanism to reduce this uncertainty, and without it people would be confronted with the complexity of considering all possibilities that involves a relationship before taking an action. Trust can be defined as an individual attitude towards another individual or group work. There is a confident expectation that the vulnerability resulting from the risk of action will not be seen as an advantage for the trusted side (Lane and Bachmann 1996).

Trust is created by the leadership, influencing relationships and job satisfaction (Martins and Von der Ohe 2002). According to Long et al. (2003) stimulating leaders is the right direction to build trust between employees and an organization in order to enhance its effectiveness. Notwithstanding of the central and decisive role of trust in leadership research, it is also considered to reduce significantly people's risk perceptions (Mayer et al. 1995) and increase their positive attitudes and desired work behaviors (Lewicki et al. 2006).

Followers, who regard their relationships with transformational leaders as interpersonal and genuine, tend to form positive affective experiences of their work (Yang and Mossholder 2010). The ability alone of leaders do not guarantee a successful organizational 
performance, so for a maximized effect of leadership it is necessary that the remaining organizational structure trusts the leader, which makes the trust effect crucial (Dias 2010).

Considering the initial perspective of Fukuyama (1995), where trust is the product of shared ethical norms, ethics consists in distinguishing correct from incorrect and then doing what is considered proper and excluding what is wrong, so ethics means to observe principles and values which rule the individual or group's ethics. Mehrabi et al. (2012) defend that since trust is formed by continuously following ethics codes, it appears that the communication of ethics codes in organizations will be the result of creating and developing trust, therefore it is a multidimensional concept that considers trust in its individual, organizational, political and social dimensions. In this context, ethics management in the organization means to identify and prioritize values in work environment and preserve their ethical performance under distressed conditions by creating ethics program (Soltani 2004).

So trust by itself is useless, it is those ethical norms that shape behavior and attitudes; hence talking about trust is a sort of shortcut for the existence of these social qualities (Mehrabi et al. 2012).

\subsection{Organizational commitment}

According to Mowday, Steers and Porter (1979) organizational commitment is the belief and acceptance of organizational objectives and values, a willingness to exercise effort on behalf of the organization and a strong desire to be part of it. For these authors the organizational commitment is still a general posture toward the organization as a whole, stabilizing the individual's behavior when circumstances change. Alexander and Tyree (1996) consider that commitment is a strong psychological and social attachment to someone or something in a social endeavor.

Despite calls in the literature in order to extend the study of commitment to other than the organization, they remain largely ignored or are relegated to a secondary position, even in countries where the issue is consolidated. Although the initial approach toward organizational commitment has one-dimensional characteristics, subsequent studies point to its multidimensionality (Rua and Araújo 2013). The multidimensional model of commitment in the organization began to be considered from the moment in which researchers found that a one-dimensional approach failed to account for the types of commitment components that were present in the binding relationship between the individual and the organization (Leite 2006).

Meyer and Allen (1991) propose a multidimensional construct of commitment, whose components reflect distinct psychological ties that link the individual to the organization. According to this model, commitment integrates affective commitment, continuance commitment, and normative commitment.

To achieve commitment within an organization the leader must have an inspiring character that is easily respected and trusted. When an individual within the organization realises that he or she receives consideration, understanding and recognition, his or her perception of commitment increases. This relation represents an important way for developing both, since there is a deliberate effort to improve performance, as individuals, regarding the reach of the project leader (Sá and Lemoine 1998). 
Leaders must often establish close communication with employees by giving feedback on their performance. This behaviour promotes organizational development and has a direct implication for organizational commitment levels (Bambacas and Patrickson 2008).

However, it is important to highlight that the leadership in an organization can facilitate, or not, the commitment of employees. It is a known fact that the style of leadership may damage the organizational climate, with direct impact in the results. Consequently leaders ought to be permanently aware of the way they work near their teams and employees (Machado 2008).

Koh and Boo (2004), studied the importance of ethical values of leadership and the relationship to organizational commitment. They concluded that values vary from person to person and it is fundamental for organizations to implement direct measures for employees to improve organizational performance.

\subsection{Conceptual framework and hypothesis}

Leadership has a key role in the results of the organizations, and change can lead to success or failure (Rua and Araújo 2013). Leaders should pay special attention to impersonal forms of trust, namely to the institutional dimension of organizational trust or to the integrity of their actions by actively supporting the development and to the maintenance of organizational trust (Ellonen et al.2008). Given the importance attached to leadership roles and the development of trust in an organization we proceed to the theoretical framework of the research model (Figure 1).

Figure 1

\section{Conceptual framework}

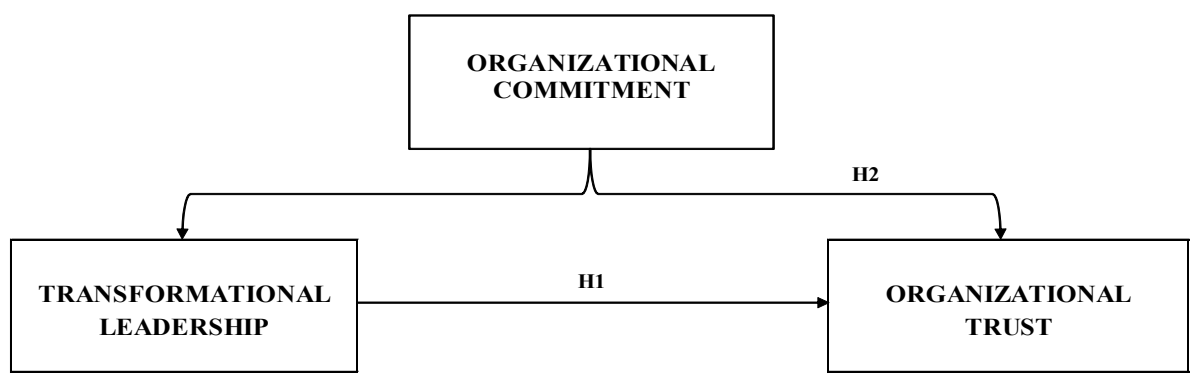

Source: Own elaboration.

When trust decreases the leadership is assumed as a differential advantage (Bibb and Kourdi 2004). When failed leadership and traditional incentives do not work, the organization's trust becomes increasingly critical. In contrast to the interpersonal and social trust, institutional trust can be understood as trust in organizational structures, processes and policies to support organizational and social interaction. 
The ability of leaders alone does not guarantee the success of organizational performance. For the purpose of leadership to be maximised it is necessary that the remaining organizational structure trusts the leader, a crucial element to the effect of organizational trust (Dias 2010).

We consider organizational trust as a fundamental aspect of leadership, as it teaches leaders to build more lasting firm relationships between the elements of an organization. Zand (1997) states that a leader's main function should be solving problems of the working group, through their knowledge and skills whose success depends heavily on followers trust.

Trust and loyalty are basic principles in a real relationship, without which there are no teams with cohesion or leadership with authenticity (Cotovio 2007).

Therefore, we hypothesise that:

H1. Transformational leadership influences levels of organizational trust.

H2. Organizational commitment has a mediating effect on the relationship between transformational leadership and organizational trust.

\section{METHODOLOGY}

\subsection{Measures}

This is an exploratory, descriptive and cross-cutting study, carried out at the Serralves Foundation (Porto, Portugal), that has as the crucial aim to analyze if organizational commitment has a mediator effect on the relation between transformational leadership and organizational trust.

This Foundation is a European-wide cultural institute at the service of the national community whose mission is to raise public awareness of contemporary art and the environment. Through a Museum of Contemporary Art, a multidisciplinary centre, an auditorium and a natural heritage park the foundation stimulates interest, reflection and debate in education, environmental issues and contemporary society (Serralves 2011).

We selected a Portuguese organization with considerable notoriety and reputation in the international cultural for this exploratory study.

In this study, employees answered a number of questions on transformational leadership, organizational trust and organizational commitment. For the assessment of transformational leadership we drew on the Organizational Citizenship Behavior (OCB), an instrument described in the study of Podsakoff et al. (1990). To examine the reliability of the OCB instrument the authors applied and found that Cronbach's alpha ranged between 0.70 and 0.85 for the scale items, previously used and adapted to Portuguese context by Rezende (2010) ${ }^{3}$. The questions used to assess organizational trust were extracted from Mayer and Gavin (2005), which found Cronbach's alpha coefficients of internal reliabilities ranging from 0.72 to 0.81 , validated for Portugal by Keating et al. (2010). Concerning the assessment of organizational commitment we resorted to Meyer and Allen (1991),

\footnotetext{
3 Questions 3, 11 and 17 of the questionnaire related to transformational leadership and marked with the letter I have reverse coded.
} 
whose Cronbach's alpha ranged from 0.69 to 0.89 , validated for Portugal by Nascimento et al. (2008).

The authors distributed a questionnaire, a common procedure in social sciences, using of a five-point Likert-type scale ranging from 1 (not true at all) to 5 (very much true), in order to better objectify the results obtained. The questionnaire allows all the related data to be collected at the same time and preserves the integrity of the variables (Bryman and Cramer 2005).

Employees of the Serralves Foundation responded individually to the questionnaire distributed between the 5th of September and the 14th of October of 2011. Data analysis was conducted using SPSS statistical software (version 19).

\subsection{Sample}

The population of individuals corresponds to all the employees of the organization in order to collect data.

However, the Foundation's Board decided that the employees associated with maintenance, particularly gardeners, assistants and others, regulated by the Park's Board, and shop employees, regulated by the Marketing and Development Board, were not to be part of this study since they considered that these people objectively did not perform functions directly related to the Foundation's main activity. These workers, distributed in technical and operational areas, correspond to a total of 35 employees.

The sample, a subset of a specific and homogeneous population, was obtained by a random process, and was reduced to 58 individuals. Of these, 43 employees answered the questionnaire, and the responses considered were 41 , since two of the questionnaires had several irregularities.

In the validated questionnaires $(n=41)$ all missing values (values not filled) were treated with a different connotation and therefore statistically correctly treated.

The results based on the sample have a confidence level of $95 \%$ and an estimated error mean of $5 \%$. The response rate of the sample was $70.7 \%$.

\section{RESULTS}

To check the reliability of the variables, we estimated the overall stability and consistency with internal Cronbach's alpha $(\alpha)$. For the present study we used the scale proposed by Pestana and Gageiro (2002). The result of 0.951 obtained for all the variables of the questionnaire is considered excellent, confirming the internal consistency of the sample. We also tested for internal consistency for the set of variables that make up each of the dimensions being studied, in order to assess the reliability thereof. We found that transformational leadership and organizational trust present excellent consistency values, respectively, 0.948 and 0.945 . Concerning organizational commitment it presents a good consistency value $(0.732)$.

We have observed that transformational leadership appears positively and moderately related to organizational trust $(\mathrm{r}=0.652, \mathrm{p}<0.05)$, as expected. For this we used the Spearman correlation coefficient. The intensity thereof is measured according to Bryman and Cramer (2005). 
Based on the linear regression model we verified the existence of a relationship between the linear variable types, without however revealing a perfectly homogeneous configuration. We can also verify that the indicated value of the coefficient of determination represented by R2 equals 0.517. According to Maroco (2007), when R2>0.500, we consider the adjustment between model and data acceptable. So we can confirm that, in the present study, there is an adjustment between transformational leadership and organizational trust (Table 1). The R2 shows that $51.7 \%$ of the variance in organizational trust is predicted by transformational leadership.

Table 1

Model summary

\begin{tabular}{|c|c|c|c|c|}
\hline Model & R & R Square & $\begin{array}{c}\text { Adjusted } \\
\text { R Square }\end{array}$ & $\begin{array}{c}\text { Std. Error of } \\
\text { the Estimate }\end{array}$ \\
\hline 1 & $.719 \mathrm{a}$ & .517 & .504 & .42502 \\
\hline
\end{tabular}

a. Predictors: (Constant), Transformational leadership.

Source: Own elaboration

In Table 2 we have done the ANOVA regression between transformational leadership and organizational trust, we have obtained an F value equal to 39.604 ( $\mathrm{p}<0.001)$, therefore $\mathrm{H} 0$ can be rejected in favour of $\mathrm{H} 1$ and we can confirm that the model supports $\mathrm{H} 1$.

Table 2

ANOVA $^{b}$

\begin{tabular}{|c|c|c|c|c|c|c|}
\hline \multicolumn{2}{|c|}{ Model } & Sum of Squares & df & Mean Square & F & Sig. \\
\hline \multirow{3}{*}{1} & Regression & 5,027 & 1 & 5,027 & 39,604 &, $000 \mathrm{a}$ \\
\cline { 2 - 7 } & Residual & 4,697 & 37 &, 127 & & \\
\cline { 2 - 8 } & Total & 9,724 & 38 & & & \\
\hline
\end{tabular}

a. Predictors: (Constant), Transformational leadership.

b. Dependent Variable: Organizational trust.

Source: Own elaboration.

The beta $(\beta)$ standardised coefficients equal 0.719 and its significance is the same as the $R$ value, as shown in table 3 . We can see that the direction of the relationship is positive, as predicted. 
Table 3

Coefficients $^{\mathrm{a}}$

\begin{tabular}{|c|c|c|c|c|c|c|}
\hline & \multirow[t]{2}{*}{ Model } & \multicolumn{2}{|c|}{ Unstandardized Coefficients } & $\begin{array}{c}\text { Standardized } \\
\text { Coefficients }\end{array}$ & \multirow[t]{2}{*}{$\mathbf{t}$} & \multirow[t]{2}{*}{ Sig. } \\
\hline & & $\mathrm{B}$ & Std. Error & Beta & & \\
\hline \multirow[b]{2}{*}{1} & (Constant) & 1.174 & .356 & & 3.300 & .002 \\
\hline & $\begin{array}{c}\text { Transformational } \\
\text { leadership }\end{array}$ & .603 & .096 & .719 & 6.293 & .000 \\
\hline
\end{tabular}

Source: Own elaboration.

According to Barron and Kenny (1986), for testing mediation as well as a more formal procedure that gives a fuller test of the extent to which the effect of the IV exerts an indirect effect on the DV through the MV we have to use the Sobel Test. Testing for mediation involves establishing four conditions (Figure 2):

1. The IV is significantly related to the DV (path c).

2. The IV is significantly related to the MV (path a).

3. The MV is significantly related to the DV (path b).

4. When controlling for the effects of the MV on the DV, the effect of the IV on the DV (path c') is no longer significant.

Figure 2

\section{Mediation model}

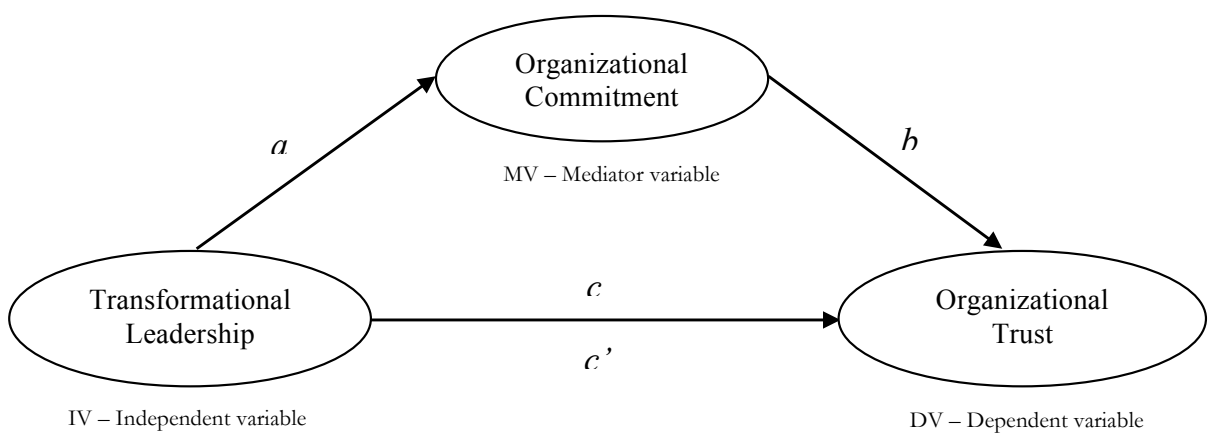

Source: Own elaboration.

We have confirmed that there is an adjustment between transformational leadership (IV) and organizational trust (DV) $\left(\mathrm{R}^{2}=0.517\right)$ and that the ANOVA regression between the same variables confirm that the model is significant $(\mathrm{F}=39.604, p<0.001)$ (tables 2 and 4 ). As there is only one predictor, beta equals 0.719 and its significance is the same as $\mathrm{R}$. Its significance is shown in table 7 , where we can see that the direction of the relationship is 
positive, as predicted. The results of this analysis show that the first condition for mediation has been met; the IV is significantly related to the DV (path c).

Relating transformational leadership (IV) and organizational commitment (MV) through the multiple linear regression analysis, the coefficient of determination $\mathrm{R}^{2}$ equals 0.154 . This shows that transformational leadership explains only $2.4 \%$ of the variance in organizational commitment. Table 4 shows that the regression model is not adjusted.

Table 4

\section{Model summary}

\begin{tabular}{|c|c|c|c|c|}
\hline Model & R & R Square & Adjusted R Square & Std. Error of the Estimate \\
\hline 1 & $.154^{\text {a }}$ & .024 & -.003 & .41795 \\
\hline
\end{tabular}

Source: Own elaboration.

In Table 5 the ANOVA regression between transformational leadership and organizational commitment reveals an $\mathrm{F}$ value equal to $0.895(p=0.350)$. This shows that the relationship between the variables and the model are not significant.

Table 5

\section{ANOVA $^{b}$}

\begin{tabular}{|c|c|c|c|c|c|c|}
\hline \multicolumn{2}{|c|}{ Model } & Sum of Squares & df & Mean Square & F & Sig. \\
\hline \multirow{3}{*}{1} & Regression & .156 & 1 & .156 & .895 & $.350 \mathrm{a}$ \\
\cline { 2 - 7 } & Residual & 6.463 & 37 & .175 & & \\
\cline { 2 - 7 } & Total & 6.620 & 38 & & & \\
\hline
\end{tabular}

a. Predictors: (Constant), Transformational leadership.

b. Dependent Variable: Organizational commitment.

Source: Own elaboration.

Beta $(\beta=0.154)$ shows that the relationship between transformational leadership and commitment, although positive, is low, contrary to predicted. So the analysis shows that the second condition for mediation has not been satisfied (path a: the IV and MV are not significantly related), as we can note on Table 6. 
Table 6

Coefficients $^{\mathrm{a}}$

\begin{tabular}{|c|c|c|c|c|c|c|}
\hline \multirow{2}{*}{ Model } & \multicolumn{2}{|c|}{ Unstandardized Coefficients } & $\begin{array}{c}\text { Standardized } \\
\text { Coefficients }\end{array}$ & \multirow{2}{*}{ T } & \multirow{2}{*}{ Sig. } \\
\cline { 3 - 5 } \multicolumn{2}{|c|}{1} & B & Std. Error & Beta & & \\
\cline { 2 - 7 } & $\begin{array}{c}\text { (Constant) } \\
\text { Transformational } \\
\text { leadership }\end{array}$ & .1003 & .417 & & 7.197 & .000 \\
\hline
\end{tabular}

a. Dependent Variable: Organizational commitment.

Source: Own elaboration.

Table 7 shows that organizational commitment explains only $0.8 \%$ of the variance in organizational trust $\left(\mathrm{R}^{2}=0.008, p=0.587\right)$ and that transformational leadership does add significantly to the variance explained ( $\mathrm{R}$ square change $=0.509, p<0.001)$.

Table 7

\section{Model Summary}

\begin{tabular}{|c|c|c|c|c|c|c|c|c|c|}
\hline \multirow{2}{*}{ Model } & \multirow{2}{*}{ R } & \multirow{2}{*}{ R Square } & $\begin{array}{c}\text { Adjusted } \\
\text { R Square }\end{array}$ & $\begin{array}{l}\text { Std. Error of } \\
\text { the Estimate }\end{array}$ & $\begin{array}{c}\text { R Square } \\
\text { Change }\end{array}$ & F Change & df1 & df2 & $\begin{array}{c}\text { Sig. F } \\
\text { Change }\end{array}$ \\
\hline 1 & $.090^{\mathrm{a}}$ & .008 & -.019 & .51057 & .008 & .300 & 1 & 37 & .587 \\
\hline 2 & $.719^{\mathrm{b}}$ & .517 & .491 & .36103 & .509 & 38.002 & 1 & 36 & .000 \\
\hline
\end{tabular}

a. Predictors: (Constant), Organizational commitment.

b. Predictors: (Constant), Organizational commitment, Transformational leadership.

Source: Own elaboration.

The ANOVA regression in Table 8 shows that the variance explained by organizational commitment is not significant $(\mathrm{F}=0.300, p=0.587)$.

Table 8

\section{ANOVA $^{b}$}

\begin{tabular}{|c|c|c|c|c|c|c|}
\hline & Model & Sum of Squares & df & Mean Square & $\mathbf{F}$ & Sig. \\
\hline \multirow{3}{*}{1} & Regression & .078 & 1 & .078 & .300 & $.587^{\mathrm{a}}$ \\
\hline & Residual & 9.645 & 37 & .261 & & \\
\hline & Total & 9.724 & 38 & & & \\
\hline \multirow{3}{*}{2} & Regression & 5.031 & 2 & 2.516 & 19.301 & $.000^{\mathrm{b}}$ \\
\hline & Residual & 4.692 & 36 & .130 & & \\
\hline & Total & 9.724 & 38 & & & \\
\hline
\end{tabular}

Source: Own elaboration. 
The regression coefficients show that organizational commitment is not significantly related to organizational trust, thus do not meet the third condition for mediation (path b: the MV is significantly related to the DV). The beta for transformational leadership (path c), which was significant in the first analysis, is still significant when controlling for the effects of the MV (path c').

It is also useful to present a figure showing the regression coefficients for the release analysis.

Figure 3

\section{Mediation model results}



Note: $\mathrm{p}<0.05$.

Source: Own elaboration.

We conclude that we cannot reject $\mathrm{H} 0$ in favour of $\mathrm{H} 2$ and therefore that organizational commitment does not have a mediator effect on the relation between transformational leadership and organizational trust, $\mathrm{H} 2$ is not confirmed by the analysis.

\section{CONCLUSIONS}

\subsection{Introduction}

The main goal of this study is to analyze how organizational commitment has a mediating effect on the relation between transformational leadership and organizational trust.

In the study we demonstrate the effects of transformational leadership in organizational trust; this relation was found to be significant and relevant and has a clear impact on the performance of employees.

Further, we concluded that organizational commitment does not mediate the relation between transformational leadership and organizational trust. This was not entirely predictable prior to this empirical study and has been substantially explained, first, by the 
fact that survey results indicate that approximately $46 \%$ of the employees do not have a stable contract link, i.e. are engaged in situations of insecurity and precarity, in which $37 \%$ remain in the institution less than 5 years. Second, only $10 \%$ of the employees wouldn't leave the organization right now given the feelings of personal obligation to the people that work with them, $2 \%$ feel that it would not be right to leave the organization at the present time even though it was an advantage for them, $10 \%$ feel very guilty if they leave the organization now, $27 \%$ believe that one of the main reasons for continuing working is the pack of benefits they have, and $17 \%$ do not consider the possibility of working for another organization, disclaiming such compromises with the organization. The fragility of the organizational commitment leads to failure of this mediator effect on the relationship between transformational leadership and organizational trust.

To achieve the commitment within an organization the leader must have an inspiring character that is easily respected and trusted, and each worker should compromise as part of the team, knowing that his/her contribution is important (Rua and Araújo 2013). When an individual perceives that is considered, understood and recognized, his/her perception of commitment increases, representing this an important way for developing both the organization, since there is a deliberate effort to improve performance, as individuals, regarding the reach of the project leader (Sá and Lemoine 1998).

The results we obtained are interesting for the comparison with similar organizations, to potential comparative studies that will lead to conclusions that enable to validate the ones found in this organization.

This conceptual framework turned out to be a tool of great interest to study the underlying issues of the presented themes. Therefore, we consider this study a relevant instrument to improve organization's management.

\subsection{Theoretical and practical implications}

This study makes a contribution to the literature by examining the mediating effect of organizational commitment on the relation between transformational leadership and organizational trust in cultural organizations. To our knowledge, these relations have not been previously empirically investigated, even though there have been studies on the relationship between the referred constructs.

In any organization, leaders should be considering the necessary attributes to obtain the confidence and commitment of employees. This study has practical implications for managers, as it draws attention to the importance of promoting a greater commitment among the organization. In our opinion the relationship between transformational leadership and organizational trust should assume a crucial role.

Some authors (e.g. Thomas et al. 2009; Colquitt et al. 2012) believe that leaders should be professional, consistent in their words and actions and support employees in achieving their goals. Consequently leaders ought to be permanently aware of the way they work near their teams and employees (Machado 2008), establish close communication with their employees and provide feedback on their performance. This behaviour promotes organizational development and has direct implication with organizational commitment levels (Bambacas and Patrickson 2008). 
In addition, our findings provide guidance for managers to promote the loyalty of employees, considering the increase of job satisfaction, establishing more stable contractual links and improving the rewarding systems (extrinsic and intrinsic), to enhance the organizational commitment.

\subsection{Limitations and future studies}

This study has some limitations that future studies can take into account, since it is a single organization study. For this reason we recommend some prudence in the analytical generalization of the results of this study; these should be carefully interpreted, limiting them to the context of the present research. All direct comparisons with existing studies in this field or extrapolation of tendencies toward studies conducted in other contexts should pay special attention to the specificity of this study.

This is a study that proposes an exploratory model of the studied themes, we consider appropriate to extend this study to other cultural organizations, increasing the amplitude of the population and sample, to confirm and validate the model, with the intend of consolidating the results presented here. Therefore, this framework should consider the development of multiple organizational studies.

Finally, we consider important to analyze other types of leadership, as well as other dimensions besides organizational trust and organizational commitment, to study how leadership can influence employees' behaviour to achieve organizational goals.

\section{REFERENCES}

Abrell, C., Rowold, J., Weibler, J. and Moenninghoff, M., 2011. Evaluation of a Longterm Transformational Leadership Development Program. Zeitschrift für Personalforschung, 25 (3), 205-224.

Alexander, K. and Tyree, J.R., 1996. Conceptualizing and measuring commitment to high school teaching. Journal of Educational Research, 89, 295-304.

Avolio, B. and Bass, B., 1991. Full-Range Training of Leadership: Manual. Binghamton, NY: Bass/Avolio \& Associates.

Bambacas, M. and Patrickson, M., 2008. Interpersonal communication skills that enhance organizational commitment. Journal of Communication Management, 12 (1), 51-72.

Baron, R.M. and Kenny, D.A., 1986. The moderator-mediator variable distinction in social psychological research: Conceptual, strategic, and statistical considerations. Journal of Personality and Social Psychology, 51, 1173-1182.

Barney, J. and Hansen, M., 1994. Trustworthiness as a source of competitive advantage. Strategic Management Journal, 15, 175-190.

Bass, B., 1985. Leadership and Performance Beyond Expectations. New York: Free Press.

Bibb, S. and Kourdi, J., 2004. Trust Matters for Organizational and Personal Success. Basingstoke: Palgrave Macmillan.

Blomqvist, K., 2002. Partnering in the dynamic environment: the role of trust in asymmetric technology partnership formation. PhD thesis. Lappeenranta University of Technology.

Bryman, A. and Cramer, D., 2005. Quantitative Data Analysis with SPSS 12 and 13: A Guide for Social Scientists. London: Routledge. 
Burns, J., 1978. Leadership. New York, NY: Harper Row.

Cherry, K., 2010. What Is Transformational Leadership? Available from: http://psychology. about.com/od/leadership/a/transformational.htm [Accessed 22 December 2011].

Connel, N. and Mannion, R., 2006. Conceptualizations of trust in the organizational literature. Journal of Health Organization and Management, 20 (5), 417-433.

Conger, J.A., 1999. Charismatic and Transformational Leadership in Organizations: An Insider's Perspective on Developing Streams of Research. Leadership Quarterly, 10, 145-179.

Costa, A., 2002. Promover a confiança em contextos organizacionais: um imperativo da prática de gestão. In: Cunha, M.P. and Rodrigues, S.B. (Org.). Manual de estudos organizacionais. Lisboa: Editora RH, 207-222.

Colquitt, J. A., LePine, J. A., Piccolo, R. F., Zapata, C. P. and Rich, B. L., 2012. Explaining the Justice-Performance Relationship: Trust as Exchange Deepener or Trust as Uncertainty Reducer? Journal of Applied Psychology, 97, 1-15.

Cotovio, V., 2007. Procura de si e liderança. Lisboa: Editorial Caminho, S.A.

Dias, H., 2010. Liderança, confiança e desempenho organizacional percebido. Tese de Mestrado, Faculdade de Economia Universidade de Coimbra, Portugal.

Dirks, K. and Ferrin, D., 2001. The role of trust in organisational settings. Organisation Science, 12 (4), 450-67.

Ellonen, R., Blomqvist, K. and Puumalainen, K., 2008. The role of trust in organizational innovativeness. European Journal of Innovation Management, 11 (2), 160-181.

Freire, C., 2008. Confiança nas Equipas de I\&D: Operacionalização de um Constructo. Revista de Estudos Politécnicos, VI (10), 165-188.

Fukuyama, F., 1995. Trust: The social virtues and the creation of prosperity. New York: The Free Press.

Huang, T., Lawler, J. and Lei, C., 2007. The effects of quality of work life on commitment and turnover intention. Social Behavior and Personality, 35 (6), 735-750. DOI: 10.2224/sbp.2007.35.6.735

Judge, T. and Piccolo, R., 2004. Transformational and Transactional Leadership: A Meta-Analytic Test of their Relative Validity. Journal of Applied Psychology, 89 (5), 755 768.

Kanungo, R., 2001. Ethical Values of Transactional and Transformational Leaders. Canadian Journal of Administrative Sciences, 18, 257-265.

Kark, R. and Shamir, B., 2002. The Dual Effect of Transformational Leadership: Priming Relational and Collective Selves and Further Effects on Followers. In: Avolio, B.J. and Yammarino, F.J. (eds.). Transformational and Charismatic Leadership: The Road Ahead. Oxford: Elsevier Science, 67-91.

Keating, J., Silva, I. and Veloso, A., 2010. Confiança organizacional: teste de um modelo. Actas do VII Simpósio Nacional de Investigação em Psicologia, Universidade do Minho, Portugal.

Kerce, E.W. and Booth-Kewley, S., 1993. Quality of work life surveys in organisations: Methods \& Benefits. In: Rosenfeld, P., Edwards, J.E. and Thomas M.D. (Eds.), Improving organisational surveys: New direction, methods and applications. Newbury Park: Sage Publications, 158-209.

Koh, H. and Boo, E., 2004. Organisational ethics and employee satisfaction and commitment. Management Decision, 42 (5), 677-693. 
Lane, C. and Bachmann, R., 1996. The social constitution of trust: supplier relations in Britain and Germany. Organization Studies, 17 (3), 365-395.

Leite, R., 2006. O empenhamento dos indivíduos nas organizações e nas profissões: uma avaliação dos efeitos das actividades extra-laborais. Tese de Doutoramento. Universidade do Minho, Portugal.

Lewicki, R.J., Tomlinson, E.C. and Gillespie, N., 2006. Models of Interpersonal Trust Development: Theoretical Approaches, Empirical Evidence, and Future Directions. Journal of Management, 32, 991-1022.

Long, C.P., Sitkin, S.B. and Cardinal, L.B., 2003. Managerial action to build control, trust, and fairness in organizations: The effect of conflict. Paper presented at the International Association of Conflict Management Conference, 15-18 June 2003, Melbourne, Australia, 1-57.

Machado, C., 2008. Comprometimento é fundamental para conquistas. Available from: http://www.artigonal.com/administracaoartigos/comprometimento-e-fundamentalpara-conquistas-519240.html [Accessed 10 September 2011].

Maroco, J., 2007 Análise Estatística com utilização do SPSS. Lisboa: Edições Sílabo, Lda.

Martins, N., and Von der Ohe, H., 2002. Trust as a factor in determining how to attract, motivate and retain talent. SA Journal of Industrial Psychology/SA Tydskrif vir Bedryfsielkunde, 28 (4), 49-57. DOI: 10.4102/sajip.v28i4.79

May, B.E., Lau, R.S. and Johnson, S.K., 1999. A longitudinal study of quality of work life and business performance. South Dakota Business Review, 58 (2), 3-7.

Mayer, R. and Gavin, M., 2005. Trust in management and performance: who minds the shop while the employees watch the boss? Academy of Management Journal, 48 (5), 874-888.

Mayer, R., Davis, J. and Schoorman, D., 1995. An integrative model of organizational trust, Academy of Management Review, 20 (3), 709-734.

Mayer, R. and Davies, J.,1999. The effect of the performance appraisal system on trust for management: a field quasi-experiment. Journal of Applied Psychology, 84 (1), 123-136.

Mehrabi, J., Javadi, M.H.M., AliAbadi, K., Tanhaei, M.H. and Samangoei, B., 2012. Studying Relationships between Tools of Ethics Management and Organizational Trust of Education Organization in City of Kermanshah Province. International Journal of Human Resource Studies, 2 (1), 139-146.

Meyer, J. and Allen, N., 1991. A three-component conceptualization of organizational commitment. Human Resources Management Review, 1 (1), 61-89.

Mowday, R.T., Steers, R.M. and Porter, L.W., 1979. The measurement of organizational commitment. Journal of Vocational Behavior, 14, 224-247.

Pestana, M. and Gageiro, J., 2002. Análise de dados para ciências sociais. A complementaridade do SPSS. Lisboa: Edições Sílabo.

Podsakoff, P., Mackenzie, S., Moorman, R. and Fetter, R., 1990. Transformational leader behaviors and their effects on followers' trust in leader, satisfaction, and organizational citizenship behavior, Leadership Quarterly, 1 (2), 107-142.

Politis, J., 2003. The connection between trust and knowledge management: What are its implications for team performance? Journal of Knowledge Management, 7 (5), 55-66. DOI: $10.1108 / 13673270310505386$

Rego, A. and Cunha, M., 2007. A Essência da Liderança - Mudança, Resultados, Integridade. (3. ${ }^{\mathrm{a}}$ ed.), Lisboa: Editora $\mathrm{RH}$. 
Rezende, H., 2010. A Liderança Transformacional e Transaccional e as suas Influências nos Comportamentos de Cidadania Organizacional. Dissertação de mestrado. ISCTE-IUL, Lisboa.

Rua, O. and Araújo, J., 2013. The influence of the transformational leadership in the organizational trust. Harvard Deusto Business Research, II (I), 55-66.

Sá, M. and Lemoine, C., 1998. O estilo de liderança como factor de comprometimento na empresa. XXII Encontro Anual da ANPAD, Foz do Iguaçu, Brasil.

Schwepker Jr, C. and Good, D., 2010. Transformational Leadership and Its Impact on Sales Force Moral Judgment, Journal of Personal Selling \& Sales Management, 30 (4), 299-318.

Serralves, 2011. Relatório e Contas 2010 da Fundação de Serralves. Available from: http://www.serralves.pt/FLIPBOOK/ReC_2010/files/relatorio $\% 20 \mathrm{e} \% 20$ contas $\% 20$ 2010 versao\%20final.pdf [Accessed 7 March 2011].

Shockley-Zalabak, P., Ellis, K. and Winograd, G., 2000. Organisational trust: what it is, why it matters. Organisation Development Journal, 18 (4), 35-48.

Soltani, M., 2004. Ethics management in the organizations, Tadbir, 132.

Thomas, G.F., Zolin, R. and Hartman, J.L., 2009. The Central Role of Communication inDeveloping Trust and Its Effect on Employee Involvement. Journal of Business Communication, 46, 287-310.

Tyler, T., 2003. Trust within organisations. Personnel Review, 32 (5), 556-568.

Van der Berg, Y. and Martins, N., 2013. The relationship between organisational trust and quality of work life. SA Journal of Human Resource Management/SA Tydskrif vir Menslikehulpbronbestuur, 11 (1), 1-13. DOI: 10.4102/ sajhrm.v11i1.392

Yang, J. and Mossholder, K.W., 2010. Examining the Effects of Trust in Leaders: A Bases-and-Foci Approach. The Leadership Quarterly, 21, 50-63.

Yukl, G.A., 1989. Leadership in Organizations. Englewood Cliffs, NJ: Prentice Hall.

Zand, D., 1997. The leadership trial: knowledge, trust, and power. New York: Oxford Press.

Zhu, Y. and Akhtar, S., 2014. The mediating effects of cognition-based trust and affect-based trust in transformational leadership's dual processes: evidence from China. The International Journal of Human Resource Management, 25 (20), 2755-2771. DOI: 10.1080/09585192.2014.934885 
